\title{
I välfärdssamhällets marginal - om socialbidragstagande bland ensamstående mödrar av svensk och utländsk härkomst
}

\author{
HUGO STRANZ \& STEFAN WIKLUND
}

\begin{abstract}
I den här artikeln analyseras socialbidragstagande bland ensamstående mödrar, med fokus riktat mot ersättningsnivåer, varaktighet, förekomst av individrelaterade problem och skillnader mellan svensk- och utrikes födda klienter. Artikeln baseras på projektet "Ensamstående mödrarvälfärd, försörjning och socialtjänst", som bygger på uppgifter om 875 slumpmässigt utvalda klienter i landets tre storstäder.
\end{abstract}

\begin{abstract}
Inledning
Ensamstående mödrar ${ }^{1}$ har under en längre tid generellt levt med sämre ekonomiska förutsättningar än de flesta andra grupper i samhället (Gähler, 2001, Skevik, 2006).

Hugo Stranz, fil dr i socialt arbete, Institutionen för socialt arbete vid Stockholms universitet

Stefan Wiklund, fil dr i socialt arbete, Institutionen för socialt arbete vid Stockholms universitet
\end{abstract}

Detta kan delvis förklaras av det enkla faktum att de är kvinnor. I jämförelse med män tjänar kvinnor mindre, arbetar i större

1 Med begreppet ensamstående mödrar avses i fortsättningen ej sammanboende kvinnor med barn under 18 år i hushållet. Det bör dock påpekas att ensamt moderskap inte alltid innebär avsaknad av partner, och behöver naturligtvis inte vara ett statiskt tillstånd (se t.ex. Gardberg Morner, 2003, Yazdanpanah, 2008). 
utsträckning deltid och har svårare att etablera sig på arbetsmarknaden (se t.ex. Gustafsson \& Johansson, 1998, Gähler, 2001). Dessutom förvärvsarbetar kvinnor i större utsträckning inom den offentliga sektorn som har ett relativt sett lägre löneläge (Nermo, 2004). Könssegregerande faktorer på arbetsmarknaden har även återverkningar på kvinnors socialförsäkringsrelaterade ersättningsnivåer (Sainsbury, 1996, Yazdanpanah, 2005), samtidigt som kvinnor traditionellt varit mer beroende av socialförsäkringarna för att trygga sin inkomst (Nyberg, 2005, Sainsbury, 2000).

Rollen som ensam familjeförsörjare är särskilt problematisk för ensamstående mödrar. Bland annat går dessa hushåll miste om de stordriftsfördelar som sammanboende har (Gähler, 2001, Sørensen, 1994), samtidigt som könsmässiga inkomstomfördelningar mellan barnens föräldrar sällan sker i motsvarande utsträckning som bland sammanboende. De ensamstående mödrarna har dessutom identifierats som en av de största ekonomiska förlorarna under 1990-talet, till följd av ökad arbetslöshet inom gruppen och svårigheter att öka förvärvsfrekvensen för dem som faktiskt har arbete (Gähler, 2001). Under 2000-talet noteras en fortsatt hög arbetslöshet och stor ekonomisk utsatthet för denna grupp (Fritzell et al., 2007, Försäkringskassan, 2009, Socialdepartementet, 2004, Skevik, 2006, Socialstyrelsen, 2010). Att de ensamstående mödrarna förlorar mark från vad som redan är en problematisk välfärdsposition är inte minst bekymmersamt mot bakgrund av det stora antalet barn som berörs.

Internationellt har vissa forskare hävdat att fattigdom är ett tillstånd som kommit att feminiseras (se t.ex. Alcock, 1993, Pearce, 1978, se även Gunnarsson, 2000). I ett internationellt perspektiv är fattigdomsutbredningen ${ }^{2}$ särskilt utmärkande bland ensamstående mödrar (Christopher, 2002, se även Lewis \& Hobson, 1997). Härvidlag är dock förekomsten väsentligt lägre i Sverige, vilket i stor utsträckning kan hänföras till den svenska välfärdsmodellens konstruktion (Christopher, 2002).

Den ekonomiska utsattheten bland ensamstående mödrar i Sverige exemplifieras av att de under en längre tid har varit kraftigt överrepresenterade bland hushåll som uppbär socialbidrag (Bergmark, 2000a, Inghe, 1960, Socialstyrelsen, 2010, Wennberg, 2008). Överrepresentationen gäller oavsett bidragstagandets varaktighet (Socialdepartementet, 2004, Socialstyrelsen, 2010) och har noterats kontinuerligt sedan 1960-talet (Inghe, 1960, Salonen, 1994). För närvarande är ungefär var femte ensamstående mamma tvungen att förlita sig på bidragsformen för att trygga sin försörjning (Socialstyrelsen, 2010). Av de barn som lever i familjer där socialbidragstagande är aktuellt, bor över hälften tillsammans med en ensamstående mor (Socialdepartementet, 2004).

Ur ett välfärdspolitiskt perspektiv kan gruppens omfattande socialbidragstagande betraktas som problematiskt. Det svenska välfärdssamhället utmärks av universalism, där transfereringar huvudsakligen sker via schematisk behovsprövning med socialförsäkringen som huvudsaklig institutionell

2 Fattigdomsgränsen är här satt till inkomster under 50 procent av den disponibla medianinkomsten. 
aktör. Socialbidragshanteringen däremot, administreras inom kommunernas individ- och familjeomsorg som i betydande utsträckning syftar till att hantera psykosociala problem av olika slag. Med andra ord är en central rationalitet inom socialbidragshanteringen att finna förklaringar och lösningar till individers problem hos dem själva.

Ensamstående mödrar har vid återkommande tillfällen pekats ut som en välfärdspolitisk förlorargrupp inom samhällsvetenskaplig forskning. Trots detta saknas central kunskap om de ekonomiskt allra mest utsatta inom gruppen - de som är i behov av socialbidrag för att trygga sin försörjning. Det saknas mer sammanhållna analyser kring socialbidragets nivåer och varaktighet för denna klientgrupp. Socialbidraget är tänkt som ett tillfälligt försörjningssystem, men såväl de utbetalade bidragssummorna som antalet bidragsmånader per år, har under de senaste decennierna ökat stadigt för bidragstagarpopulationen generellt (Socialstyrelsen, 2010). Det råder emellertid brist på systematiska analyser om mönstret avspeglas för gruppen ensamstående mödrar specifikt (se dock Bergmark \& Bäckman, 2004, 2007 för analyser kring utträden ur bidragstagande).

Socialbidragstagande har kopplingar till en rad faktorer på såväl strukturell som individuell nivå. Till exempel är betydelsen av sysselsättning, liksom sambanden mellan socialbidragstagande och psykosocial problematik, sedan tidigare känd bland bidragstagare generellt (se t.ex. Bergmark, 1991, Byberg, 2002). I vilken utsträckning individrelaterad problematik (t.ex. missbruk eller psykiska besvär) förekommer bland ensamstående mödrar är dock i allt väsentligt okänt. En eventuellt omfattande förekomst av sådan problematik inom gruppen, skulle kunna beskrivas som en utlösande faktor (jfr Korpi, 1971).

I kommande analyser avser vi att separera utrikes födda från svenskfödda ${ }^{3}$ ensamstående mödrar. Invandrare - exklusive flyktinghushåll - utgör omkring en tredjedel av samtliga bidragshushåll. Inom ramen för gruppen ensamstående mödrar är andelarna högre - runt 40 procent (Socialstyrelsen, 2010). Forskning har visat att bidragets funktion och bestämningar i flera avseenden skiljer sig åt mellan svenskar och invandrare överlag (Franzén, 2002). Däremot saknas kunskaper om i vilken utsträckning motsvarande mönster i bidragstagande och problembilder märks bland ensamstående mödrar.

I artikeln rapporteras de första resultaten från projektet "Ensamstående mödrar - välfärd, försörjning och socialtjänst". Materialet utgörs av enkäter som har besvarats av ansvariga socialsekreterare för 875 slumpmässigt utvalda individer inom gruppen. Syftet med artikeln är att beskriva och analysera socialbidragstagande bland ensamstående mödrar. Ett vidare syfte är att systematiskt jämföra bidragstagande bland svenskar och utrikes födda inom gruppen. Följande frågeställningar beaktas:

1. Vilken betydelse har socialbidraget bland ensamstående mödrar med avseende på ersättningsnivåer och varaktighet?

3 Vi utgår alltså från förstagenerationsinvandrare snarare än individer av utländsk härkomst (där föräldrarna födda i annat land). 
2. I vilken utsträckning förekommer individrelaterade problem inom gruppen?

3. Finns det skillnader mellan ensamstående mödrar av svensk respektive utländsk härkomst med avseende på bidragets nivåer, varaktighet samt problembilder?

\section{Bakgrund}

\section{Socialbidragstagande- utveckling och nivåer}

Socialbidraget brukar beskrivas som samhällets sista ekonomiska skyddsnät. I denna egenskap kan andelen bidragstagare i befolkningen för det första ses som en indikator på hur väl den generella välfärdspolitikens transfereringar och socialförsäkring fungerar. För det andra kan en snedvriden fördelning av bidragstagare mellan olika grupper ses som ett uttryck för brister i välfärdssamhällets fördelnings- eller välfärdspolitik (se t.ex. Bergmark, 2000a).

Under 1900-talet har andelen bidragstagare i befolkningen varierat mellan 4-9 procent (Salonen, 2000). Sedan 1960-talets mitt har bidragstagandet $i$ hög grad varit konjunkturellt anknutet, vilket inneburit ökningar med avseende på kostnader, genomsnittliga bidragstider och andel berörda hushåll i samband med lågkonjunkturer (se t.ex. Salonen, 2000). De högsta andelarna i modern tid - 8,5 procent - konstaterades under den ekonomiska recessionen på 1990-talet (Bergmark, 2000). Under 2000-talet har andelen hushåll med socialbidrag minskat relativt kontinuerligt och låg 2009 på omkring 6 procent (Socialstyrelsen, 2010). Samtidigt svarar 2000-talet för ett trendbrott i det att de genomsnittliga bidragstiderna - och därmed bidragskostnaderna - trots konjunkturuppgångar, återfinns på en fortsatt hög nivå (jfr Bergmark \& Bäckman, 2007, Socialstyrelsen, 2010).

Ensamstående mödrar har under de senaste decennierna konstant varit den familjekonstellation som haft flest bidragstagare inom sin grupp. Hushållstypen ökade drastiskt under 1960-talet i takt med att familjesplittring blev allt vanligare samtidigt som socialbidragets betydelse för gruppens ekonomi över tid kom att bli allt viktigare. Mellan 1965-1985 ökade de ensamstående mödrarnas relativa bidragstagande från runt 25 procent till närmare 45 procent (Salonen, 1994). ${ }^{4}$

Även under 1990-talet var ensamstående mödrar den hushållstyp med högst andel socialbidragstagare inom sin grupp, där decenniets toppnivå låg runt 35 procent (Bergmark, 2000a). Andelarna baseras på offentlig statistik där det således finns jämförbarhetsproblem med Salonens siffror. Gruppens bidragstagande ökade dock inte i samma omfattning som för invandrare och ungdomar under 25 år, vilka var de som drabbades hårdast av recessionen (Franzén, 2002). En förklaring till den relativt sett återhållsamma utvecklingen inom gruppen var deras låga representation inom invandrar- respektive ungdomsgruppen.

4 Salonen använder sig av data från Folk- och Bostadsräkningen vid beräkningar av bruttopopulationens storlek medan den officiella statistiken använder sig av AKU. Salonen redovisar generellt högre andelar jämfört med den officiella statistiken som han menar underskattar de reella siffrorna. 
Liksom för de flesta grupper har det relativa bidragstagandet bland ensamstående mödrar minskat sedan 1990-talets slut (Socialstyrelsen, 2010). År 2009 uppbar drygt 20 procent inom gruppen socialbidrag, vilket alltjämt är den i särklass högsta representationen bland olika hushållstyper. Som jämförelse kan nämnas att motsvarande siffra för befolkningen generellt är 6 procent och för ensamstående fäder 7 procent (Socialstyrelsen, 2010).

Trots de senaste årens minskning i bidragstagande i befolkningen överlag, är det sammantagna intrycket att socialbidraget har kommit att bli en allt viktigare försörjningskälla för dem som faktiskt mottar socialbidrag. Trots att bidraget är tänkt att fungera som en utväg för individer med tillfälliga ekonomiska problem, har såväl bidragstagandets varaktighet som ersättningsnivåerna ökat väsentligt. Det genomsnittliga antalet bidragsmånader per år har ökat från omkring 4 månader år 1990 till drygt 6 månader 2009, vilket är den högsta siffran i modern tid (Socialstyrelsen, 2010). Socialbidragets betydelse som försörjningssystem reflekteras dessutom i det att ersättningsnivåerna per biståndsmånad i fasta priser har ökat under 2000-talet med cirka 20 procent (Socialstyrelsen, 2010). Det är således tänkbart att socialbidraget kan ha intagit en allt starkare funktion för ensamstående mödrar i termer av såväl andelar av den disponibla inkomsten som vad gäller varaktighet över tid.

Långvarigt socialbidragstagande - som i de flesta offentliga beräkningar likställs med minst tio månaders bidragstagande under ett kalenderår (s.k. nettovaraktighet) (Socialstyrelsen, 1999) - har behandlats i flera studier (se t.ex. Bergmark \& Bäckman, 2004, 2007, Jonasson, 1996, Stranz, 2002). Andelen ensamstående mödrar som uppbär socialbidrag långvarigt, överensstämmer med vad som gäller för socialbidragstagarpopulationen i dess helhet, dvs. drygt 30 procent (Socialstyrelsen, 2010).

\section{Faktorer som påverkar socialbidragstagande}

En betydande del av socialbidragsforskningen uppehåller sig kring frågor om bidragstagandets orsaker. Ovan beskrivna variationer över tid i bidragens nyttjandegrad, nivåer, varaktighet samt fördelning bland olika grupper i samhället kan ses som konkreta uttryck för bidragsformens dynamik och relativa känslighet för omvärldsfaktorer (jfr Salonen, 2000). Samtidigt bör det påpekas att vissa forskare menar att till exempel nivåerna på socialbidragets utbredning i befolkningen har en förvånansvärd historisk stabilitet med tanke på mängden av sociala reformer som har skett under det senaste århundradet (Bergmark, 2000a).

Det saknas en mer vedertagen teoretisk förklaringsmodell för socialbidragets orsaker, men ofta används typologier där man separerar analysnivåerna som avses. Två centrala analysnivåer utgörs av strukturell respektive individuell nivå (jfr Bergmark, 2000a, Salonen, 2000)5. Trots analytiska förtjänster med sådana typologier, förenklar

5 Det bör påpekas att viss forskning på området även fokuserat förklaringar på organisationsnivå (t.ex. Byberg, 2002, Minas, 2005). 
de bilden av de komplicerade processer som ligger bakom socialbidragstagande. Ytterst är det rimligt att sluta sig till att bidragstagande är ett uttryck för en rad samvarierande faktorer som verkar inom och mellan dessa olika nivåer (jämför Salonen, 2000).

Till den strukturella nivån kan faktorer som sysselsättning, de offentliga trygghetssystemens utformning samt demografi hänföras. Arbetslöshet har i flera studier etablerat starka samband med tidsmässiga och kommunala variationer i bidragsnivåer (Bergmark \& Sandgren, 1998, Byberg, 2002, Schwartz \& Puide, 1993). Överlag är sambandet indirekt och går via andelen ej arbetslöshetsförsäkrade. I detta avseende har det dock påvisats regionala variationer, där man i storstäderna kunna fastställa högre bidragskostnader med kontroll för andel oförsäkrade arbetslösa (Aguilar \& Gustafsson, 1992, Bergmark \& Sandgren, 1998, Byberg, 2002). För ensamstående mödrar kunde man till exempel under krisåren på 1990-talet påvisa en särskilt sårbar ställning på arbetsmarknaden med ökande andelar arbetslösa och i tidsbegränsade anställningsformer (Gähler, 2001).

Inom det socialpolitiska trygghetssystemet beskrivs ofta socialbidragen och socialförsäkringarna som kommunicerande kärl, där förändringar i ersättningsnivåer och kvalifikationskrav i socialförsäkringen har mer eller mindre direkta återverkningar i socialbidragstagandet (Bergmark, 2000a). Empiriska studier har pekat på övervältringseffekter vid inskränkningar i socialförsäkringssystemet (Salonen, 1997). Simuleringar på mikronivå har också visat, att ensamstående mödrars socialbidragstagande kan förväntas öka mer än för andra grupper, när olika ersättningar från socialförsäkringen fiktivt försämras (SOU 1994:46, se även Bergmark, 2000a).

Bland demografiska faktorer har andelen ensamstående mödrar, liksom andelen invandrare i befolkningen haft ett starkt förklaringsvärde för variationer i bidragstagande (Bergmark \& Sandgren, 1998, Byberg, 2002, Halleröd, 1991, Salonen, 1994, Schwartz \& Puide, 1993, Wennberg, 2008). På individnivå har det emellertid visats att invandrares vistelsetid samvarierar med minskat bidragstagande, där risken är jämförbar med svenskar efter 15 år i landet (Franzén, 2002).

Bland individrelaterade faktorer, har man hos bidragstagare generellt noterat höga andelar missbruksproblem. Andelarna varierar mellan olika studier, delvis beroende på skillnader i hur dessa designats, men kan antas ligga inom intervallet 20-35 procent (Bergmark, 1991, Jonasson, 1996, Pettersson, 1986, Stranz, 2002). Förekomsten av psykisk respektive fysisk ohälsa ligger på ungefär motsvarande nivår som missbruksproblem (Bergmark, 1991, Jonasson, 1996, Nybom et al., 2005, Pettersson, 1986, Socialstyrelsen, 1999). Generellt överlappar individrelaterade faktorer ofta varandra (Nybom et al., 2005, Socialstyrelsen, 1999)

Till individnivån kan också sökbeteende hänföras. Generellt kan sägas att det saknas empiriskt stöd för att individers sökbeteende leder till ett överutnyttjande av systemet. Snarare har studier visat att många människor som har rätt att erhålla bidrag undviker att söka, bl. a. till följd av skuldoch skamkänslor (Mood, 2004, Starrin et al., 2003). Det finns vissa omständigheter som pekar mot ett svagare sökbeteende bland 
ensamstående mödrar än för andra grupper. Internationellt har visats att rädslan för att barnet/barnen kan komma att omhändertas minskar mödrarnas villighet att söka kontakt med sociala myndigheter vid ekonomiska problem (Canvin et al., 2007).

Som ovan nämnts, kan strukturella och individuella faktorer knappast ses som ömsesidigt uteslutande kategorier. Med andra ord kan bidragstagandet inte alltid ses som antingen strukturellt eller individuellt betingat - ibland är det möjligt att betrakta samma fenomen utifrån olika analysnivåer. Exempelvis kan arbetslöshet diskuteras i mer strukturella termer som tar sikte på konjunkturella fluktuationer. Samtidigt är det möjligt att beskriva arbetslöshet som ett individuellt problem för den enskilde bidragstagaren.

Ett sätt att analytiskt förhålla sig till kopplingen mellan strukturella och individuella faktorer utgörs av Korpis (1971) modell. Författaren särskiljer mellan grundläggande, betingande och utlösande faktorer till socialbidragstagande. Något förenklat utgörs grundläggande faktorer av socialt skiktande krafter på strukturell nivå, medan betingande faktorer representerar tillhörigheten $\mathrm{i}$ grupper med statistiska överrisker för bidragstagande. Att vara ensamstående moder kan alltså ses som en betingande faktor för bidragstagande, vilket skulle kunna tolkas som ett uttryck för grundläggande könssegregerande faktorer på strukturell nivå. Utlösande faktorer beskriver orsaksförhållanden på individnivå, där exempelvis individrelaterade problem (missbruk, psykisk ohälsa, etc.) kan ses som mer omedelbara orsaker till bidragstagande.
Det bör påpekas att Korpis modell har vissa begränsningar för analyser av tvärsnittsdata, eftersom man utifrån prevalenser av individrelaterade problem vid ett givet mättillfälle inte kan dra slutsatsen att dessa initialt utlöst bidragsbehovet (jfr Bergmark, 1991). Dock innefattar modellen begrepp som möjliggör en mer nyanserad diskussion av kopplingen mellan strukturella och individuella faktorer.

\section{Material och metod}

Studiens population utgörs av samtliga ensamstående mödrar - bosatta i någon av storstäderna Göteborg (19 stadsdelar), ${ }^{6}$ Malmö (10 stadsdelar) och Stockholm (14 stadsdelar) - som uppbar socialbidrag (exklusive s.k. introduktionsersättning, som i första hand utgår till nyanlända flyktingar) någon gång under 2007 ( $N=8$ 434). ${ }^{7}$ Skälen att begränsa urvalsramen till de tre storstäderna är främst forskningsekonomiska. Samplet består av 895 slumpmässigt utvalda ärenden, alltså drygt 10 procent av hela gruppen. ${ }^{8}$ Slumpningen gjordes utifrån listor över bidragstagare, som statistikpro-

6 Göteborg omfattar totalt 21 stadsdelar. I 2 av dessa var antalet hushåll av den aktuella typen alltför få - 8 respektive 11 - för att stadsdelarna skulle komma att omfattas i urvalet.

7 Göteborg (N=3 323), Malmö (N=1 818), Stockholm ( $N=3293)$.

8 För att täcka upp för eventuellt bortfall, och ändå spegla runt 10 procent av populationen, drogs initialt ett urval om 900 ärenden. I samband med datainsamlingens påbörjande visade sig totalt 5 ärenden vara felregistreringar (annan hushållstyp). 
ducerande enheter inom respektive stad sammanställde särskilt för studiens vidkommande.

Materialet består av detaljerade uppgifter på klientnivå som inhämtades via enkäter under perioden maj-december 2008 direkt från de socialsekreterare ( $\mathrm{n}=451$ ) som ansvarade för handläggningen av ärendet (se nedan). Slumpningen har gjorts systematiskt, varför klienterna är proportionerligt spridda i förhållande till antal bidragstagare per stad och stadsdel. Omkring 20 procent av ärendena är insamlade i Malmö och de resterande är jämnt fördelade mellan Stockholm och Göteborg. Det externa bortfallet uppgår till omkring 2 procent, vilket ger en slutgiltig undersökningsgrupp om 875 ärenden.

Utöver bakgrundsinformation om klienterna, spände formuläret över fem övergripande områden: utbildning/arbetsmarknad, socialbidragstagande/försörjning, hälsa (somatisk/psykisk/psykosocial), handläggning samt barnet/-en i familjen. Merparten av enkäten efterfrågade uppgifter som finns i socialtjänstens sekretesskyddade akter. Genom att ställa frågor direkt till ansvariga socialsekreterare, har även information som inte alltid finns dokumenterad kunnat inhämtas (t.ex. förekomst av psykosociala problem och överväganden kring barnet/-en i familjen). Dessutom ställdes frågor kring klienterna där socialarbetarna ombads lämna mer värderande/uppskattade uppgifter om klienterna. Exempel på det senare är att socialsekreterarna fick ange i vilken utsträckning de bedömer att klienten lider av olika hälsorelaterade eller psykosociala problem, att rangordna de orsaker de såg som avgörande för klientens bidragsbehov, om man övervägt att anmäla barnet/-en för barnavårdsutredning, etc.

Studien har godkänts vid regionala etikprövningsnämnden i Stockholm. För att öka datas tillförlitlighet, förbereddes datainsamlingsarbetet i flera led: inledningsvis kontaktades samtliga stadsdelsförvaltningars IFO-chefer eller motsvarande per brev, med information om projektets syfte, det praktiska datainsamlingsupplägget, $\mathrm{mm}$. Från samtliga stadsdelsförvaltningar inhämtades också formella tillstånd att ta del av aktuella individdata, samt därefter grundläggande registeruppgifter om den aktuella populationen. Med stöd av registeruppgifterna matchades urvalet mot den socialsekreterare som fattat det senaste socialbidragsbeslutet. Efter genomfört urval kontaktades stadsdelarna av en projektmedarbetare, som bokade tillfällen för arbetsplatsförlagda besök av forskargruppen vid respektive socialkontor. Inför besöken tilldelades förvaltningarna uppgifter om vilka socialsekreterare som, i och med sitt ansvar för de utvalda ärendena, var direkt berörda av det fortsatta arbetet.

I samband med de arbetsplatsförlagda besöken samlades samtliga socialsekreterare i en gemensam lokal, där de gavs information om forskningsprojektet, dess upplägg och den insats som efterfrågades av dem. Mötet innefattade också en genomgång av ovan nämnda enkät, varefter formulär märkta med vissa centrala uppgifter (personnummer, registrerade socialbidragsutbetalningar, etc.) kring utvalda klienter distribuerades till ansvariga handläggare. Totalt genomfördes 38 arbetsplatsförlagda besök. Avvikelsen i förhållande till det totala antalet berörda stadsdelar (43 
stycken) var i första hand avhängig organisatoriska förutsättningar, exempelvis att flera stadsdelar valt att samordna sin handläggning.

Inhämtandet av data direkt från ansvariga socialsekreterare möjliggjorde att samla in uppgifter som inte låter sig fångas via registerstudier. Dessutom kunde kända problem med registerdata hanteras, exempelvis bristande stabilitet som kan uppstå till följd av dålig noggrannhet vid inmatning av uppgifter (jfr t.ex. Byberg, 2002). Metoden har också medfört att de delar av materialet som är av renodlad registertyp, till exempel utbetalade socialbidragsbelopp och antal månader klienten mottagit bidrag, har kunnat valideras direkt av socialsekreterarna i samband med att de besvarat formulärets övriga delar. Det skall dock understrykas att tillvägagångssättet medför att det är socialarbetarnas - inte klienternas - bedömningar och uppfattningar som ligger till grund för den inhämtade informationen. Det är inte givet att dessa parter betraktar situationen på samma sätt (Nybom et al., 2005).

Det högsta internbortfallet avser olika inkomstposter där 150 fall (cirka 15 procent) av uppgifterna är ofullständiga (här har socialsekreterarna angivit förekomst/ avsaknad av vissa ersättningar, men inte kunnat uppge aktuella beloppsnivåer). Dessa fall är exkluderade i kommande beräkningar. Därutöver är internbortfallet genomgående lågt. I två frågor (födelseland samt antal arbetstimmar/vecka) uppgår internbortfallet till omkring fyra respektive åtta procent, annars förekommer endast enstaka bortfall.

Ett förhållande som har konsekvenser för materialets validitet har att göra med personalomsättningen vid socialkontoren. I de fall då ansvarig handläggare hade lämnat sin anställning (uppskattningsvis 10-20 procent av fallen, instrumentet täckte inte detta) instruerades övriga socialsekreterare att i samarbete komplettera den information som fanns i journalanteckningar med uppgifter som kan ha framkommit $\mathrm{i}$ samband med ärendedragningar, etc. Det samordnande ansvaret för kompletteringsarbetet ålades respektive stadsdels enhetschef/1:e socialsekreterare.

I strikt statistisk mening kan resultaten endast generaliseras till landets tre största städer. I urvalet finns emellertid en bred representation av stadsdelar med olika strukturella förutsättningar, varför det är rimligt att anta att resultaten kan ha viss giltighet för förhållanden i andra kommuner. Det gäller framför allt för de kranskommuner som omger storstäderna. Generaliseringar utanför storstadsområdena försvåras primärt av att vissa strukturella förutsättningar - demografi, arbetsmarknadsläge, etc. - är unika för dessa regioner. Det är till exempel sedan tidigare känt att både andelen ej arbetslöshetsförsäkrade och andelen utomnordiska invandrare är påtagligt högre i storstäderna än i övriga landet (se t.ex. Bergmark \& Sandgren, 1998, Franzén, 2002). Som framgått är detta exempel på faktorer som utgör markörer för socialbidragstagandets omfattning, varför samplet är något snedvridet ur ett riksrepresentativt hänseende. Det bör dock påpekas att urvalet speglar en stor del av landets befolkning då omkring 20 procent är bosatta i Stockholm, Göteborg eller Malmö. 
Det bör också påpekas att vi, beträffande varaktighet, undersökt antal bidragsmånader för varje individ år 2007 retrospektivt, vilket är konsistent med den metod som används i offentlig statistik. Beträffande ersättningsnivåer har vi undersökt senaste utbetalningen 2007 retrospektivt. Retrospektiva data fångar normalt högre andelar kortvariga bidragstagare (jfr Dahl \& Lorentzen, 2003). Detta medför att man kan förvänta sig att de genom- snittliga ersättningsnivåerna $\mathrm{i}$ vårt urval är lägre jämfört med om vi skulle ha använt en prospektiv design, eftersom kortvariga bidragstagare generellt har lägre ersättningsnivåer (Dahlberg et al., 2009).

\section{Undersökningsgruppen- grundläggande uppgifter}

I Tabell 1 presenteras samplet med utgångs-

\section{Tabell I.}

Basuppgifter för ensamstående mödrar med socialbidrag. Procent och medelvärden (standardavvikelser iparentes). ${ }^{1}$

\begin{tabular}{|c|c|c|c|c|}
\hline & $\begin{array}{l}\text { Hela gruppen } \\
(n=702-875)^{2}\end{array}$ & $\begin{array}{l}\text { Svenskar } \\
(n=222-298)\end{array}$ & $\begin{array}{l}\text { Invandrare } \\
(n=384-538)\end{array}$ & $\mathbf{p}$ \\
\hline \multicolumn{5}{|l|}{ Familj och utbildning } \\
\hline Moderns ålder (m) & $36,2(8,9)$ & 35,5 & 36,6 & * \\
\hline $\begin{array}{l}\text { Antal hemmavarande barn (m) } \\
\text { Utbildningsnivå }\end{array}$ & $1,8(1,0)$ & 1,5 & 2,0 & ***** \\
\hline Grundskola (påbörjad/avslutad) & 56 & 47 & 61 & **⿻丷木 \\
\hline Gymnasium (eller motsvarande) & 36 & 49 & 30 & **** \\
\hline Universitet & 8 & 4 & 9 & * \\
\hline \multicolumn{5}{|l|}{$\begin{array}{l}\text { Bostadsförhållanden } \\
\text { Typ av boende }\end{array}$} \\
\hline Bostadsrätt & 2 & 5 & I & *** \\
\hline Hyresrätt, I :a hand & 77 & 75 & 77 & NS \\
\hline Hyresrätt, 2:a hand & 16 & 18 & 15 & NS \\
\hline Inneboende, etc. & 5 & 2 & 7 & $*$ \\
\hline Antal rum i bostaden (m) & $3,0(0,8)$ & 2,9 & 3,1 & **⿻丷木大 \\
\hline Antal rum/familjemedlem $(m)^{3}$ & $0,8(0,8)$ & 0,8 & 0,7 & NS \\
\hline
\end{tabular}

$\mathrm{t}=\mathrm{p}<0,10^{*}=\mathrm{p}<0,05^{* *}=\mathrm{p}<0,01^{* * *}=\mathrm{p}<0,001$

${ }^{1}$ Medelvärden har signifikansprövats med t-test och frekvensfördelningar med Fisher's Exact Test.

${ }^{2}$ Variationerna i $n$ är ett resultat av att socialarbetarna uppgivit att de inte vet hur ett visst förhållande ser ut för den aktuella klienten. Avvikelserna gäller dels utbildningsnivå, dels antalet rum i bostaden.

${ }^{3}$ Kök och vardagsrum exkluderade. 
punkt i ett antal basuppgifter. Presentationen avser dels samplet i dess helhet, dels görs en uppdelning mellan utrikes födda ${ }^{9}$ (omkring 65 procent av gruppen) respektive svenskfödda (omkring 35 procent) klienter. Systematiska jämförelser med bidragstagare $i$ allmänhet låter sig inte göras (eftersom offentlig statistik för dessa uppgifter inte alltid finns), men den höga andelen utrikes födda illustrerar att storstäderna (och därmed samplet) i detta avseende avviker från riket som helhet (jfr Socialstyrelsen, 2010).

Som framgår av tabellen är den genomsnittliga bidragstagaren drygt 36 år och en majoritet, omkring 65 procent, av klienterna ligger i åldersspannet 30-49 år. Härvidlag avviker undersökningsgruppen från bidragstagarkollektivet i dess helhet, som över tid kommit att utmärkas av ökade andelar yngre personer (se t.ex. Salonen, 2000). 2009 var drygt 40 procent av bidragstagarna under 30 år (Socialstyrelsen, 2010). I föreliggande material uppgår andelen yngre (18-29 år) bland de utrikes födda till omkring 20 procent, medan motsvarande andelar bland de svenskfödda är omkring 10 procentenheter högre (visas ej i tabellen).

Antalet hemmavarande barn uppgår i genomsnitt till knappt två per hushåll och invandrargruppen försörjer fler barn. En majoritet av klienterna saknar utbildning utöver grundskola (drygt en tredjedel har inte avslutat grundskolestudierna).

9 Drygt 40 procent av de utrikes födda klienterna härstammar från Mellanöstern och omkring 25 procent vardera från Afrika (primärt Somalia, Etiopien och Eritrea) och Europa (primärt forna Jugoslavien).
Utbildningsnivån varierar markant mellan svenskar och invandrare. Nära nog samtliga klienter bor i en hyreslägenhet och den genomsnittliga klienten är dessutom att betrakta som trångbodd. ${ }^{10}$

\section{Resultat}

I resultatredovisningen görs en tematisk uppdelning mellan å ena sidan aspekter som fokuserar de ensamstående mödrarnas sysselsättning och inkomster (inklusive bidragstagande), å andra sidan förhållanden som avser problembilder, insatser och handläggningsrutiner.

Av Tabell 2 framgår att 75 procent av samtliga klienter är arbetslösa. Bland dem som har sysselsättning, är deltidsarbete i någon omfattning vanligast. I samstämmighet med tidigare forskning är merparten omkring 90 procent - bland såväl de arbetslösa som de deltidsarbetande klienterna inte a-kasseanslutna. Andelen del- respektive heltidsarbetande är mer än dubbelt så hög bland svenskfödda hushåll, medan de utrikes födda kvinnorna i högre grad studerar. Kategorin studerande kvinnor innefattar alltifrån personer som är temporärt i behov av socialbidrag till följd av exempelvis skollov, till sådana som genomgår någon längre yrkesförankrad utbildningsinsats.

De utrikes födda hushållens högre representation bland dem som är registrerade som arbetslösa är till stor del ett resultat av att man studerar SFI (svenska för

10 Enligt trångboddhetsnorm 3, som är satt till ett rum per familjemedlem (exklusive kök och vardagsrum). 
invandrare); omkring en tredjedel $(\mathrm{n}=118)$ av utrikes födda kvinnor inom ramen för kategorin arbetslösa bedriver SFI-studier. Eftersom urvalet inte omfattar s.k. introduktionsersättning, där socialbidraget i det närmaste utgår som ett studiestöd kopplat till SFI-studier (jfr Franzén, 2002), utgörs den SFI-studerande delen av gruppen sannolikt av kvinnor som av olika skäl har haft svårt att tillgodogöra sig sina studier. Oavsett vilka dessa skäl är - avbrott i studierna till följd av graviditet, analfabetism, hälsorelaterade hinder, etc. - tyder mycket på att de SFI-studerande kvinnorna är särskilt utsatta, inte minst rent ekonomiskt. Graden av bidragsbehov framstår som mer utmärkande bland de SFI-studerande kvinnorna. Det genomsnittliga antalet månader

\section{Tabell 2.}

Ensamstående mödrars sysselsättning, inkomster och socialbidragstagande. Procent och medelvärden (standardavvikelser i parentes). ${ }^{1}$

\begin{tabular}{|c|c|c|c|c|}
\hline & $\begin{array}{l}\text { Hela gruppen } \\
(n=7 \mid 4-868)^{2}\end{array}$ & $\begin{array}{l}\text { Svenskar } \\
(n=250-297)^{2}\end{array}$ & $\begin{array}{l}\text { Invandrare } \\
(n=435-533)^{2}\end{array}$ & $\mathbf{p}$ \\
\hline \multicolumn{5}{|l|}{ Sysselsättning (\%) } \\
\hline Arbetslös (inkl SFI) & 75 & 68 & 79 & *** \\
\hline Studerande & 8 & 6 & 9 & NS \\
\hline Deltidsarbetande & 12 & 18 & 9 & *** \\
\hline Heltidsarbetande & 5 & 8 & 3 & *** \\
\hline \multirow{2}{*}{\multicolumn{5}{|c|}{$\begin{array}{l}\text { Inkomster/transfereringar }{ }^{3}(\mathrm{~m}) \\
\text { Nettoinkomster }\end{array}$}} \\
\hline & & & & \\
\hline Förvärvsinkomster & I 920 (3084) & $2738(3568)$ & | 407 (2 633) & **** \\
\hline Socialbidrag & $6006(3632)$ & $5860(3535)$ & $6|4|(3210)$ & NS \\
\hline Övriga bidrag och transfereringar & $6088(3335)$ & $5103(2935)$ & $6655(3881)$ & **** \\
\hline Totalinkomster & $\begin{array}{l}140 \mid 4 \\
(4287)\end{array}$ & $13700(4086)$ & $14202(4382)$ & NS \\
\hline $\begin{array}{l}\text { Disponibel inkomst per konsum- } \\
\text { tionsenhet }\end{array}$ & $7170(1995)$ & $7437(2$ | 25) & $7019(1929)$ & **⿻丷木 \\
\hline \multicolumn{5}{|l|}{ Socialbidragstagande } \\
\hline Antal år sedan aktualisering (m) & $4,5(4,3)$ & $5,1(4,9)$ & $4,3(3,9)$ & * \\
\hline Antal bidragsmånader 2007 (m) & $7,4(4,2)$ & $6,4(4,3)$ & $8,1 \mid(4,0)$ & ***** \\
\hline $\begin{array}{l}\text { Andel långvariga ( } 10 \text { - } 12 \text { månader) } \\
\text { bidragstagare } 2007 \text { (\%) }\end{array}$ & 43 & 33 & 49 & **** \\
\hline
\end{tabular}

$\mathrm{t}=\mathrm{p}<0,10^{*}=\mathrm{p}<0,05^{* *}=\mathrm{p}<0,01^{* * *}=\mathrm{p}<0,001$

${ }^{1}$ Medelvärden har signifikansprövats med t-test och frekvensfördelningar med Fisher's Exact Test.

${ }^{2} n$ varierar till följd av internt bortfall i inkomstvariablerna

${ }^{3}$ Inkomsterna avser den senaste månaden för socialbidragsutbetalning.

Hugo Stranz \& Stefan Wiklund: I välfärdssamhällets marginal... 
dessa kvinnor har uppburit socialbidrag avviker signifikant ${ }^{11}$ i förhållande till ickestuderande - omkring två månader ytterligare under både 2006 och 2007.

Den genomsnittliga totalinkomsten i klientgruppen $(n=714)^{12},{ }^{13}$ uppgår till drygt 14000 kronor under en given månad. I Tabell 2 bryts inkomsterna upp i tre olika kategorier - förvärvsinkomster, socialbidrag samt övriga bidrag/transfereringar. Den senare kategorin innefattar ersättningar knutna till socialförsäkringen; dels skattepliktiga inkomster som sjuk- och föräldrapenning, dels skattefria bidrag/ersättningar som barnbidrag och underhållsstöd. Socialbidraget svarar, oavsett om hushållet är av svensk eller utländsk härkomst, i genomsnitt för omkring 40 procent av de ensamstående mödrarnas totala inkomster. Förvärvsinkomsterna skiljer sig inom gruppen och följer sysselsättningsmönstren bland de svensk- respektive utrikes födda klienterna - de förra erhåller i genomsnitt

11 Sambanden är prövade med t-test, $\mathrm{p}=0,000$ respektive 0,001 .

$12 n$ har justerats ner dels till följd av tidigare nämnda internbortfall på enskilda inkomstuppgifter, samt i totalt elva fall med anledning av att klientens sammantagna inkomst betraktas som outlier ( $>27000$ kronor).

13 I det materialet saknar en majoritet $(\mathrm{n}=461)$ av klienterna förvärvsinkomster, vilket gör medianinkomster till ett mindre lämpligt mått. För att skapa enhetlighet i presentationen, redovisas därför genomgående gruppens medelinkomster. Särskilda analyser av medianinkomsterna (där detta är tillämpligt), visar på små skillnader mellan medel- och medianvärden. Skillnaderna mellan svenskars och invandrares medianinkomster är fortsatt signifikanta (kontrollerat via Mann-Whitney test). runt 20 procent av inkomsterna från förvärvsarbete, medan förvärvsinkomsternas andel av totalinkomsterna bland utrikes födda är ungefär hälften så stor. Bland utrikes födda är inkomstandelarna från socialförsäkringen däremot högre.

De disponibla inkomsterna har beräknats enligt den svenska konsumtionsenhetsskalan (KE), då inkomsten justeras efter hushållens storlek (för vidare diskussion, se t.ex. Socialdepartementet, 2004, SOU 2002:73). Av Tabell 2 framgår att de genomsnittliga inkomsterna per konsumtionsenhet uppgår till knappt 7200 kronor, samt att differensen mellan svensk- och utrikes födda hushåll är drygt 400 kronor. Av SCB:s offentliga inkomststatistik framgår att motsvarande uppgifter för normalpopulationen ensamstående mödrar året innan, dvs. år 2006, uppgick till omkring 10000 kronor.

I den avslutande delen av Tabell 2 redovisas aspekter av varaktighet i bidragstagandet. För gruppen som helhet kan konstateras att socialbidragstagandet är relativt etablerat. För det första var det i genomsnitt omkring 4,5 år sedan undersökningstillfället som man för första gången ansökte om socialbidrag. Denna uppgift avser dessutom enbart när man första gången aktualiserades i den stadsdel man uppbar bidrag i. Det kan dock inte uteslutas att klienterna tidigare mottagit socialbidrag i en annan stadsdel eller kommun. Svenskfödda hushåll har varit aktualiserade väsentligt längre tid än utrikes födda. En uppenbar förklaring är att de utrikes födda klienterna har befunnit sig kortare tid i landet än svenskfödda. I övrigt framstår bidragstagandet bland utrikes födda som mer varak- 
tigt än bland svenskfödda. Det genomsnittliga antalet bidragsmånader bland utrikes födda uppgår till strax över åtta månader under det aktuella året, medan det för de svenskfödda återfinns mer i paritet med de genomsnittliga sex månader som enligt Socialstyrelsens (2010) beräkningar gäller för bidragstagargruppen som helhet. Därtill är nästan hälften av bidragstagarna i invandrargruppen, mot omkring en tredje- del bland de svenskfödda, att betrakta som långvariga enligt definitionen 10-12 månaders bidragstagande under ett kalenderår.

Av Tabell 3 framgår inledningsvis andelen klienter med individrelaterad problematik. Psykisk ohälsa förekommer i strax under 30 procent av fallen, medan somatisk ohälsa och olika former av psykosocial problematik - till exempel att kvinnan är våldsutsatt, befinner sig i vårdnadstvist

\section{Tabell 3.}

Ensamstående mödrar: förekomst av individrelaterade problem, aktualiseringsorsak samt insatser och handläggningsrutiner. Procent. ${ }^{1}$

\begin{tabular}{|c|c|c|c|c|}
\hline & $\begin{array}{l}\text { Hela gruppen } \\
(n=87 \mid-875)^{2}\end{array}$ & $\begin{array}{l}\text { Svenskar } \\
(n=295-298)^{2}\end{array}$ & $\begin{array}{l}\text { Invandrare } \\
(n=535-538)^{2}\end{array}$ & $\mathbf{p}$ \\
\hline \multicolumn{5}{|l|}{ Individrelaterade problem } \\
\hline Somatisk ohälsa & 27 & 31 & 26 & NS \\
\hline Psykisk ohälsa & 29 & 37 & 25 & *** \\
\hline Missbruk & 4 & 9 & I & **** \\
\hline Annan psykosocial problematik & 22 & 23 & 21 & NS \\
\hline \multicolumn{5}{|l|}{ Aktualiseringsorsak (\%) } \\
\hline Avsaknad av sysselsättning & 49 & 39 & 55 & **** \\
\hline Otillräckliga förvärvsinkomster & 10 & 14 & 8 & $* *$ \\
\hline $\begin{array}{l}\text { Otillräcklig ersättning socialför- } \\
\text { säkring }\end{array}$ & 19 & 20 & 19 & NS \\
\hline Fysisk/psykisk ohälsa & 17 & 20 & 16 & NS \\
\hline Psykosocial problematik & 5 & 7 & 3 & * \\
\hline \multicolumn{5}{|l|}{$\begin{array}{l}\text { Insatser och handläggnings- } \\
\text { rutiner (\%) }\end{array}$} \\
\hline Arbetsmarknadsinsats & 39 & 37 & 41 & NS \\
\hline Kontakt vårdgivare & 23 & 29 & 21 & $*$ \\
\hline Psykosocial insats socialtjänst & 14 & 15 & 14 & NS \\
\hline Budget-/skuldrådgivning & 7 & 9 & 5 & $\dagger$ \\
\hline Förenklad handläggning & 48 & 36 & 54 & $* * *$ \\
\hline
\end{tabular}

$\dagger=p<0,10^{*}=p<0,05^{* *}=p<0,01^{* * *}=p<0,001$

${ }^{1}$ Signifikansprövningar med Fisher's Exact Test.

${ }^{2} n$ varierar till följd av internt bortfall.

Hugo Stranz \& Stefan Wiklund: I välfärdssamhällets marginal... 
eller uppvisar tecken på icke diagnostiserade begåvningshandikapp eller motsvarande - noteras i en dryg femtedel av fallen. Förekomsten av dessa problem stämmer i stora drag överens med vad som framkommit i tidigare forskning, samtidigt som andelen klienter med missbruksproblem fyra procent - är lägre än vad som har rapporterats i tidigare studier (se t.ex. Stranz, 2002). Generellt är förekomsten av hälsorelaterade och/eller psykosociala hinder särskilt framträdande bland de svenskfödda ensamstående mödrarna. Särskilt iögonfallande är förekomsten av psykisk ohälsa respektive missbruksproblem. En dryg tredjedel av de svenskfödda klienterna uppvisar någon form av psykisk ohälsa och missbruksproblem framstår som ett problem som i princip enbart förekommer bland de svenskfödda.

Uppgifterna om aktualiseringsorsaker baseras på socialarbetarnas uppfattningar om vilket det mest avgörande skälet till klientens socialbidragsbehov är. ${ }^{14}$ Trots

14 Med utgångspunkt i frågan "Vilka orsaker anser du var bidragande till den aktuella klientens behov av socialbidrag vid det sista utbetalningstillfället 2007?", har socialarbetarna uppmanats rangordna förekomsten av totalt nio olika hinder/orsaker. Uppgifterna i Tabell 3 sammanfattar de hinder/orsaker socialarbetarna förstarankat. I övrigt fördelar sig svaren (andel socialarbetare som anger att hinder/ orsak förekommer, oaktat vilken rangordnad betydelse detta ges) enligt följande: arbetslöshet (56), otillräckliga inkomster (13), otillräcklig ersättning från försäkringskassa (32), otillräcklig ersättning från a-kassa (6), missbruk (4), somatisk ohälsa (19), psykisk ohälsa (22), våldsutsatt (7), andra skäl (28). att förekomsten av individrelaterade problem är utbredd, anser socialarbetarna att sådana problem endast har betydelse för bidragsbehovet för drygt 20 procent av undersökningsgruppen. Psykosociala problem - som bl. a. innefattar missbruksproblem och förekomst av våld från närstående - beskrivs som en vanligare aktualiseringsorsak bland svenskfödda klienter. För tio procent av gruppen uppges otillräckliga inkomster vara det främsta skälet till behovet av socialbidrag. Skillnaderna mellan de utrikes födda respektive svenskfödda hushållen är påtagliga, men stämmer på det hela taget överens med de differenser i sysselsättningsgrad som gäller för respektive delgrupp (se Tabell 2). Det genomgående mest centrala skälet till klienternas behov av socialbidrag är arbetslöshet, vars avgörande betydelse särskilt märks bland invandrare.

Arbetslöshetens framträdande betydelse för klienternas socialbidragstagande avspeglas i vilka insatser som mottas. Omkring 40 procent av gruppen erhåller någon form av arbetsmarknadsinsats. Skillnaderna mellan vilka insatser som mottas av svensk- och utrikes födda klienter, är i stora drag en spegling av vilka problem som lyfts fram som mest framträdande inom respektive delgrupp. Till de utrikes födda klienterna förmedlas arbetsmarknadsrelaterade insatser i större utsträckning än till de svenskfödda. För svenskfödda är däremot etablerade kontakter med landstingsanknutna vårdgivare mer frekvent förekommande. Vidare framgår att en påtagligt större andel svensk- än utrikes födda klienter är föremål för budget-/skuldrådgivning, som är en av få renodlade socialtjänst- 
insatser med huvudsakligt fokus inriktat mot individens ekonomiska förhållningssätt (Bergmark, 2000b). I Tabell 3 framgår avslutningsvis att endast en dryg tredjedel av de svenskfödda handläggs förenklat, medan handläggningsformen används för majoriteten av utrikes födda.

\section{Sammanfattande diskussion}

I denna artikel har vi beskrivit och analyserat socialbidragets ersättningsnivåer och varaktighet bland ensamstående mödrar samt redogjort för de problembilder som finns inom klientgruppen. Vi har dessutom presenterat systematiska jämförelser mellan svenskar och invandrare inom gruppen. I strikt statistisk mening kan undersökningen generaliseras till landets tre storstäder. De huvudsakliga resultaten är följande:

- I genomsnitt svarar socialbidraget för omkring 40 procent av gruppens totalinkomster. Varaktigheten i bidragstagandet är knappt 7,5 månader, vilket nästan är 1,5 månader längre än för bidragstagare i allmänhet.

- Individrelaterade problem förekommer i någon form bland en knapp tredjedel av klienterna. Såväl fysisk som psykisk ohälsa förekommer i ungefär motsvarande utsträckning som för bidragstagare i allmänhet. Missbruksproblem förekommer i väsentligt lägre grad. Socialtjänstens individinriktade arbete med gruppen är främst koncentrerat till arbetsmarknadsoriente- rade insatser, medan insatser för att möta psykosocial problematik märks i mindre utsträckning. Förenklade handläggningsrutiner förekommer för nästan hälften av gruppen.

- Bidragstagandet skiljer sig i väsentliga avseenden bland svensk- respektive utrikes födda ensamstående mödrar:

- Invandrare har lägre disponibel inkomst per konsumtionsenhet. Även om ersättningsnivåerna inte skiljer sig nämnvärt mellan svenskar och invandrare, kompenserar inte bidraget för den lägre inkomst invandrare har från arbete och socialförsäkring.

- Bidragstagandets varaktighet är i genomsnitt nästan två månader längre för invandrare jämfört med svenskar.

- Individrelaterade problem förekommer i lägre grad bland invandrare jämfört med svenskar. Detta gäller särskilt för psykisk ohälsa och missbruk. Kontakter med vårdgivare liksom budget-l skuldrådgivning förekommer i mindre utsträckning bland invandrare. Förenklad handläggning är väsentligt vanligare bland invandrare.

I artikeln har vi således visat att socialbidraget inte bara är ett utbrett försörjningsalternativ för många ensamstående mödrar - det är dessutom en betydande försörjningskälla för dem som faktiskt nyttjar systemet. Bidragsformen svarar för drygt 40 procent av gruppens totala nettoinkomst och bidragstagandets varaktighet är 
väsentligt längre än för den genomsnittlige bidragstagaren. Därmed finns fog att hävda, att bidragstagande bland ensamstående mödrar inte bara är vanligare än inom andra grupper - för dem är socialbidragssystemet dessutom en viktigare försörjningskälla.

Trots att individrelaterade problem särskilt psykisk ohälsa - är vanliga bland ensamstående mödrar, är utbredningen inte iögonfallande jämfört med andra bidragstagargrupper. Det är till och med så att missbruk är väsentligt mindre vanligt inom undersökningsgruppen. Dessutom sker bidragshanteringen ofta förenklat dvs. i form av mer rutinmässiga utbetalningar, där fokus i mindre utsträckning läggs på klientens individuella problematik. Även handläggarnas bedömningar indikerar att strukturellt betingade faktorer tillskrivs störst betydelse vid bestämningen av de viktigaste orsakerna bakom klienternas bidragstagande.

Prevalenser av individrelaterade problem förefaller alltså inte vara större $i$ undersökningsgruppen jämfört med andra bidragstagare. Således kan gruppens överrepresentation bland bidragstagare svårligen reduceras till förklaringsfaktorer på individnivå - till exempel av karaktären att ensamstående mödrar oftare än andra skulle ha psykosociala problem som alienerar dem från arbetsmarknaden. Utifrån Korpis (1971) tidigare beskrivna distinktion mellan grundläggande (strukturellt skiktande krafter), betingande (riskgruppstillhörighet) och utlösande ${ }^{15}$ (individrela-

15 Det bör återigen påpekas att kausala samband är svåra att fastställa, särskilt med stöd av tvärsnittsdata. terade) faktorer, framstår således förklaringar till gruppens bidragstagande inte $\mathrm{i}$ större utsträckning än för andra grupper kunna hänföras till den sista kategorin. Detta kan i sin tur tolkas som att grundläggande orsaksfaktorer (t.ex. könssegregerande faktorer på strukturell nivå) i förening med en mer allmänt stark betingning (t.ex. beroende av att hushållstypen går miste om gifta/sambos stordriftsfördelar samt att könsmässiga inkomstomfördelningar från fadern till modern sker i lägre utsträckning i dessa familjer) har väsentligt större inflytande för gruppens bidragstagande.

Implikationerna av en sådan tolkning kan naturligtvis ses som problematisk. För närvarande är var femte ensamstående mor tvungen att förlita sig till ett försörjningssystem som i all väsentligt söker lösningar till försörjningsproblematiken hos klienterna själva, samtidigt som individuell problematik inom gruppen inte är vanligare förekommande än bland andra. I förlängningen är det tänkbart att gruppens höga exponeringsgrad för socialbidragssystemet dessutom kan generera andra slags marginaliserande effekter än renodlat ekonomiska. Det är exempelvis sedan tidigare känt att barn till ensamstående mödrar är starkt överrepresenterade bland barn i samhällsvård (t.ex. Lundström \& Sallnäs, 2003). Det är inte otänkbart att gruppens höga exponeringsgrad för socialbidragssystemet bidrar i sådana klientskapande processer (jfr Lundström \& Wiklund, 2000).

Vi har också visat att ovan beskrivna mönster för ensamstående mödrars bidragstagande är väsentligt mer framträdande bland utrikes födda. Med andra ord 
är det möjligt att identifiera en delgrupp inom gruppen ensamstående mödrar - som utgör en betydande andel av populationen - där socialbidragssystemet utgör en ännu viktigare försörjningskälla och där bidragstagandets kopplingar till förklaringsfaktorer på strukturell nivå förefaller vara ännu starkare. Härvidlag finns således beröringspunkter mellan socialbidragstagande bland ensamstående mödrar av utländsk härkomst och bidragsmönster bland andra typer av utrikes födda hushåll.

Socialbidraget avser att hantera individers tillfälliga ekonomiska problem. Under de senaste två decennierna har systemet dock blivit allt mer institutionaliserat som permanent försörjningskälla för många människor. Detta går stick i stäv mot bakomliggande intentioner med socialbidraget i en bredare socialpolitisk kontext. Överlag kan utvecklingen betraktas som problematisk. Ett allt mer institutionaliserat bidragstagande bland dem som är i behov av systemet, kan ses som ett uttryck för ökad marginalisering i samhället. I denna artikel har vi visat att en sådan marginalisering inte är jämt fördelad bland olika grupper av bidragstagare. Utifrån våra data har vi dessutom visat att det är svårt att finna stöd för att marginaliseringen har uppenbara kopplingar till problem av exempelvis psykosocial karaktär.

Som vi påpekat har det tidigare saknats mer sammanhållna analyser av ensamstående mödrars bidragstagande. Detta är i sig förvånande, inte minst med tanke på att gruppen under 40 år varit starkt överrepresenterad i ett försörjningssystem som i grunden avviker från generella drag i svensk välfärdspolitik. I kommande artiklar avser vi att presentera mer ingående sambandsanalyser av bidragstagandet bland ensamstående mödrar, där inte minst bestämningar till bidragstagandets varaktighet är en viktig forskningsfråga.

\section{Referenser}

Aguilar, R. \& Gustafsson, B. (1992). Social Assistance and Public Expenditures (Memorandum no 168). Göteborg: Göteborgs universitet, Handelshögskolan.

Alcock, P. (1993). Understanding Poverty. Basingstoke: Macmillan.

Andrén, T. \& Gustafsson, B. (2004). Patterns of social assistance receipt in Sweden. International Journal of Social Welfare, vol. 13 (1), ss. 55-68.

Bergmark, Å. (1991). Socialbidrag och försörjning. En studie av bidragstagande bland ensamstående utan barn (Rapport i socialt arbete, nr 55). Stockholm: Stockholms universitet, Institutio- nen för socialt arbete.

Bergmark, Å. (2000a). Socialbidragen under 1990talet. I Bergmark, Å. (red.), Välfärd och försörjning (SOU 2000:40). Stockholm: Fritzes, ss. 129-170.

Bergmark, A. (2000b). Arbete med socialbidrag - organisation, metoder och insatser. I Puide, A. (red.), Socialbidrag i forskning och praktik. Stockholm: Gothia, ss. 147-163.

Bergmark, Å. \& Sandgren, P. (1998). Vilka faktorer bestämmer socialbidragskostnaderna? En analys av kommunala variationer. Stockholm: Socialstyrelsen.

Bergmark, A. \& Bäckman, O. (2004). Stuck with 
Welfare? Long-term Social Assistance Recipiency in Sweden. European Sociological Review, vol. 20 (5), ss. 425-443.

Bergmark, Å. \& Bäckman, O. (2007). Socialbidragstagandets dynamik - varaktighet och utträden från socialbidragstagande under 2000-talet. Socialvetenskaplig tidskrift, vol. 14 (2-3), ss. 134-152.

Byberg, I. (2002). Kontroll eller handlingsfrihet? en studie av organiseringens betydelse $i$ socialbidragsarbetet (Rapport i socialt arbete, $\mathrm{nr}$ 101). Stockholm: Stockholms universitet, Institutionen för socialt arbete.

Canvin, K., Jones, C., Marttila, A. Burström, B. \& Whitehead, M. (2007). Can I risk using public services? Perceived consequences of seeking help and health care among households living in poverty: qualitative study. Journal of Epidemiology \& Community Health, vol. 61 (11), ss. 984-989.

Christopher, K. (2002). Single Motherhood, Employment, or Social Assistance: Why Are U.S. Women Poorer Than Women in Other Affluent Nations? Journal of Poverty, vol. 6 (2), ss. 61-80.

Dahl, E. \& Lorentzen, T. (2003). Dynamics of social assistance: the Norwegian experience in comparative perspective. International Journal of Social Welfare, vol. 12 (4), ss. 289-301.

Dahlberg, M., Edmark, K., Hansen, J. \& Mörk, E. (2009). Fattigdom i folkhemmet - frän socialbidrag till självförsörjning. Uppsala: Institutet för arbetsmarknadspolitisk utvärdering (IFAU) Rapport 2009:4.

Franzén, E. M. (2002). I välfärdsstatens väntrum - studier av invandrares socialbidragstagande (Skriftserien 2002:5). Göteborg: Göteborgs universitet, Institutionen för socialt arbete.

Fritzell, J., Gähler, M. \& Nermo, M. (2007). Vad hände med 1990-talets stora förlorargrupper? Välfärd och ofärd under 2000-talet. Socialvetenskaplig tidskrift, vol. 14(2-3), ss. 110-133.

Försäkringskassan (2009). Ensamstående föräldrars ekonomiska situation (Socialförsäkringsrapport 2009:4). Stockholm: Försäkringskassan.
Gardberg Morner, C. (2003). Självständigt beroende. Ensamstående mammors försörjningsstrategier (Göteborg Studies in Sociology, no. 18). Göteborg: Göteborgs universitet, Sociologiska institutionen.

Gunnarsson, E. (2000). Kvinnors fattigdom - könsperspektivet I forskningen om socialbidrag och fattigdom. Socialvetenskaplig tidskrift, vol. 7 (1-2), ss. 57-71.

Gustafsson, B \& Johansson, M. (1998). Earnings inequality and the gender gap: an accounting exercise for Sweden 1975-1991. Labour, vol. 12 (4), ss. 715-744.

Gähler, M. (2001). Bara en mor - ensamstående mödrars ekonomiska levnadsvillkor i 1990talets Sverige. I Bergmark, Å. (red.), Ofärd i välfärden (SOU 2001:54). Stockholm: Fritzes, ss. 15-100.

Halleröd, B. (1991). Den svenska fattigdomen. Lund: Arkiv.

Inghe, G. (1960). Fattiga i folkhemmet. Stockholm: Stockholms kommunalförvaltning, $\mathrm{nr} 24$.

Jonasson, I. (1996). Långvariga socialbidragstagare (Rapport i socialt arbete, nr 80). Stockholm: Stockholms universitet, Institutionen för socialt arbete.

Korpi, W. (1971). Fattigdom i välfärden. Stockholm: Tiden.

Lewis, J. \& Hobson, B. (1997). Introduction. I Lewis, J. (red.), Lone mothers in European welfare regimes: shifting policy logics. London: Jessica Kingsley Publishers, ss. 1-20.

Lundström, T. \& Sallnäs, M. (2003). Klass, kön och etnicitet i den sociala barnavården. Socialvetenskaplig tidskrift, vol. 10 (2-3), ss. 193-213.

Lundström, T. \& Wiklund, S. (2000). Att växa upp i familjer med långvarigt försörjningsstöd. En forskningsöversikt om barns uppväxtvillkor $i$ familjer med socialbidrag och små ekonomiska resurser. Stockholm: FoU.

Minas, R. (2005). Administrating Poverty-Studies of Intake Organization and Social Assistance in Sweden (Stockholm Social Studies of Social Work - 21). Stockholm: Stockholms universitet, Institutionen för socialt arbete.

Mood, C. (2004). Social Influence Effects on Social 
Assistance Recipiency. Acta Sociologica, vol. 47 (3), ss. 235-251.

Nermo, M. (2004). Sida vid sida men inte på jobbet: en analys av könssegregerade arbetsmarknader. I Florin, C. \& Bergqvist, C. (red.), Framtiden i samtiden: könsrelationer i förändring $i$ Sverige och omvärlden. Stockholm: Institutet för framtidsstudier, ss. 108-139.

Nyberg, A. (2005). Har den ekonomiska jämställdheten ökat sedan början av 1990-talet? I Forskarrapporter till Jämställdhetspolitiska utredningen (SOU 2005:66). Stockholm: Fritzes, ss. 13-84.

Nybom, J. (Red.), Puide, A., Roselius, M. \& Hjulström, F. (2005). Förutsättningar för socialbidragsarbete - en jämförelse mellan fyra kommuner. Stockholm: IMS

Pearce, D. (1978). The Feminization of Poverty: Women, Work and Welfare. The Urban and Social Change Review, vol. 11 (1-2), ss. 28-36.

Pettersson, U. (1986). Socialtjänsten i praktiken. Från mål till verklighet. Stockholm: Skeab.

Sainsbury, D. (1996). Gender, equality, and welfare states. Cambridge: Cambridge University Press.

Sainsbury, D. (2000). Välfärdsutvecklingen för kvinnor och män på 1990-talet. I Bergmark, Å. (red.), Välfärd och försörjning (SOU 2000:40). Stockholm: Fritzes, ss. 87-128.

Salonen, T. (1994). Välfärdens marginaler. Stockholm: Fritzes.

Salonen, T. (1997). Övervältringar från socialförsäkringar till socialbidrag (Meddelanden från Socialhögskolan, 1997:8). Lund: Lunds universitet.

Salonen, T. (2000). Hundra år av understöd. I Puide, A. (red.), Socialbidrag i forskning och praktik. Stockholm: Gothia, ss. 31-60.

Schwartz, B. \& Puide, A. (1993). Kommunala kostnadsvariationer - en studie om området Individ- och familjeomsorg (EFI Research Paper 6507). Stockholm: Handelshögskolan, Ekonomiska forskningsinstitutet.

Skevik, A. (2006). Lone motherhood in the Nordic countries: sole providers in dual-breadwinner regimes. I Ellingsæter, A. L. \& Arnlaug, L. (red.), Politicising parenthood in Scandinavia. Gender relations in welfare states. Bristol: Policy Press, ss. 241-264.

Socialdepartementet (2004). Ekonomiskt utsatta barn (Ds 2004:41) Stockholm: Socialdepartementet.

Socialstyrelsen. (1999). Långvarigt socialbidragstagande under 1990-talet. Stockholm: Socialstyrelsen.

Socialstyrelsen (2010) Ekonomiskt bistånd årsstatistik år 2010. Utbetalda belopp samt antal mottagare och antal biståndshushåll. Stockholm: Socialstyrelsen.

SOU 1994:46. Sambandet mellan samhällsekonomi, transfereringar och socialbidrag. Stockholm: Fritzes.

SOU 2002:73. Förbättrad statistik om hushållens inkomster. Stockholm: Fritzes.

Starrin, B., Kalander Blomkvist, M. \& Jansson, S. (2003). Socialbidragstagande och statusbunden skamkänsla - en prövning av ekonomi-sociala band modellen. Socialvetenskaplig tidskrift, vol. 10 (1), ss. 24-47.

Stranz, H. (2002). Långvarigt socialbidragstagande - en studie i två kommuner. Stockholm: Svenska Kommunförbundet.

Sørensen, A. (1994). Women`s economic risk and the economic position of single mothers. European Sociological Review, vol. 10 (2), ss. 173188.

Wennberg, L. (2008). Social Security for Solo Mothers in Swedish and EU law. On the constructions of normality and the boundaries of social citizenship (Umeå Studies in Law, no. 18). Umeå: Umeå universitet.

Yazdanpanah, S. (2005). Att få livet att gå ihop: om lågavlönade kvinnors inkomstkällor. I Forskarrapporter till Jämställdhetspolitiska utredningen (SOU 2005:66). Stockholm: Fritzes, ss. 85-132.

Yazdanpanah, S. (2008). Att upprätthålla livet. Om lågavlönade ensamstående mödrars försörjning i Sverige (Stockholm Studies in Economic History, no. 54). Stockholm: Stockholms universitet, Ekonomisk-historiska institutionen.

Hugo Stranz \& Stefan Wiklund: I välfärdssamhällets marginal... 


\section{Summary}

\section{In the margins of the Swedish welfare state Social assistance recipiency amonglone mothers of native and non-native origin}

The economic position of lone mothers in Sweden is far more problematic than for other households. Currently, about 20 per cent of Swedish lone mothers depend on social assistance to secure their economic situation, in comparison to 5 per cent of the overall Swedish population. The aim of this article is to describe and analyse social assistance recipiency among single mothers as well as differences between those of native and non-native origin. The main focus is on the duration of dependency, benefit levels and the presence of individual impairments (e.g. psychosocial problems, psychiatric and/or somatic impairments, etc.).

Data consist of a cross-sectional and randomly selected sample ( $\mathrm{n}=875$ ) of lone mothers receiving means-tested social assistance during 2007 in Stockholm, Gothenburg or Malmö. Data were collected using a comprehensive questionnaire, covering detailed information on client level. Case managers served as informants and external as well as internal response rates in the study were generally high.

The main findings are: (1) About 40 per cent of total income within the group originate from social assistance and the average duration is about 1.5 months longer annually compared to the gross population of recipients. (2) Individual conditions and impairments are present within a third of the sample. While the presence of health impairments correspond to prevalences within the gross population of recipients, psychosocial problems (e.g. substance abuse) are less common. (3) There are substantial variations between native and non-natives within the group. As regards the latter group, (a) social assistance does not compensate for lower levels of disposable income; (b) individual conditions and impairments are less common; and (c) duration of recipiency is about two months longer on average. Overall, this indicates that recipiency among non-natives is more closely associated with factors on the structural level. 